\title{
The yield of white melilot seeds depending on the width between rows and doses of nitrogen fertilizer
}

\author{
Vozhegova R. ${ }^{1}$, Vlashchuk A. ${ }^{2}$, Drobit A. ${ }^{3}$, Vlashchuk $0 .{ }^{4}$ \\ Institute of Irrigated Agriculture of NAAS \\ sett. Naddnipryanske, Kherson, 73483, Ukraine \\ e-mail: ${ }^{1} i z z . u a @ u k r . n e t,{ }^{2} i z z . n a s i n n y t s t v o @ u k r . n e t,{ }^{3}$ KolpakovaLesya80@gmail.com
}

Goal. To establish features of formation of elements of structure and productivity of seeds of a white melilot of the varieties Pivdennyi and Donetskyi Odnorichnyi depending on the width of interrow and doses of nitrogen fertilizer in non-irrigated conditions of the South of Ukraine. Methods. Field - to monitor the growth and development of plants, weather, and environmental conditions and other factors under study; visual - to detect phenological changes of melilot plants; measuring and weighing - to determine parameters of yield structure and yield; mathematical and statistical - to carry out variance analysis and statistical data processing to assess the reliability of the research results. Results. Optimization of the elements of the technology of growing white melilot influences the seed productivity of the crop. Studies have shown that the variety Pivdennyi in non-irrigated conditions of the South of Ukraine forms $38 \mathrm{~kg} / \mathrm{ha}$, or $9.1 \%$ higher seed yield compared to the variety Donetskyi Odnorichnyi. The maximum average seed yield at the level of $439 \mathrm{~kg} / \mathrm{ha}$ was gained at $45 \mathrm{~cm}$ width between rows, which is $8.4-19.6 \%$ higher than in other rows. Conclusions. It was fixed that the greatest influence on the formation of seed productivity of the crop had a dose of nitrogen fertilizer (factor $\mathrm{C}$ ) $-71.21 \%$, the share of varietal composition (factor A) was $6.3 \%$, row spacing (factor B) $-17.2 \%$. On average for $2016-$ 2018 , the maximum seed yield of $556 \mathrm{~kg} / \mathrm{ha}$ was obtained by sowing white maillot of the variety Pivdennyi using a row spacing of $45 \mathrm{~cm}$ and applying a dose of nitrogen fertilizer N60.

Key words: legumes, variety, structural indicators, seed productivity.

DOI: https://doi.org/10.31073/agrovisnyk202105-02

All protein-rich legumes accumulate biological nitrogen in the soil, promote the formation of humus and improve soil structure. With the introduction into production of uncommon but highly productive legumes, multifunctional in use, soil fertility increases, crop production increases and the deficit of feed and protein decreases [1-3].

In modern economic relations, agricultural enterprises of various forms of ownership are forced to look for new forms and methods of management. Of particular importance is the search for new nontraditional niche crops that would be profitable and do not violate crop rotations $[4,5]$.

In the zone of risky agriculture, which includes the South of Ukraine, the choice of drought-resistant plants capable of forming stable yields of high quality seeds in extreme conditions is of great importance. These requirements are fully met by the annual white clover - a culture of universal use, drought - and heat-resistant, relatively undemanding to soils, technological [6, 7].

This species is one of the best green manures with nitrogen fixation functions, which fits perfectly into modern short-rotation crop rotations of the steppe region. It has a set of valuable economic and ecological and biological features. Therefore, the introduction of this plant will contribute to the greening and biologization of crop production, the introduction of environmentally friendly advanced technologies and efficient production of high quality energy-rich feeds. Many farms, especially livestock, use clover to feed animals [8-10].

One-year-old white clover is in great demand among agricultural producers. The most reliable way to obtain high yields of crop seeds is to improve the technology of cultivation, based on the establishment of an effective method of sowing and the dose of fertilizers [11, 12].

However, there are no recommendations for agricultural techniques of this crop. Requires further study of the optimization of the technology of growing white annual clover in order to increase seed productivity and accelerate the introduction of the crop into production. Therefore, studies aimed at determining the optimal parameters of the main elements of the technology of growing varieties of clover Southern and Donetsk annual in non-irrigated conditions are relevant.

Goal. To establish features of formation of elements of structure and productivity of seeds of a white melilot of the varieties Pivdennyi and Donetskyi Odnorichnyi depending on the width of interrow and doses of nitrogen fertilizer in non-irrigated conditions of the South of Ukraine.

Materials and research methods. Field and laboratory studies were conducted during 2016-2018 in the research field of the Institute of Irrigated Agriculture of NAAS in the department of primary and elite seed production in accordance with generally accepted methods of field research, guidelines and based on the tasks of NAAS 22.01.05.08. PSH "Improve the technology of growing seeds of a new 
variety of white annual clover in the Southern Steppe of Ukraine" (№ state registration 0116U001125) and 22.01.05.09. PSH "To determine the seed productivity of white annual clover depending on the use of elements of agricultural machinery" (№ state registration 0117U002225).

The development of the research problem on the topic of the work combined theoretical and experimental tests based on a systems approach. The soil of the experimental site is dark-chestnut medium-loamy slightly saline on the carbonate forest, typical for the irrigated zone of the South of Ukraine. The arable layer of the soil contained $2,2-2,5 \%$ of humus, the amount of which gradually decreased with depth. In a 3-factor field experiment, we studied the structural parameters and seed productivity of white clover varieties of annual domestic selection depending on the width between rows and doses of nitrogen fertilizer in rainy conditions.

Factor A - varieties of white annual clover Southern and Donetsk annual (reproduction - superelite), factor B - row spacing $-15 \mathrm{~cm}, 30,45$ and $60 \mathrm{~cm}$, factor $C$ - doses of nitrogen fertilizer - without fertilizers $-\mathrm{N}_{30}, \mathrm{~N}_{60}, \mathrm{~N}_{90}$. The experiment, laid down by the method of split plots, was performed in 4-fold repetition with the placement of plots randomized according to the method of field research [13, 14]. The estimated area of the plots is $25 \mathrm{~m}^{2}$.

Research results. The formation of productivity of any crop depends on many factors: soil and climatic conditions, growing area, varietal or hybrid composition, seed quality, row spacing, nitrogen fertilizer application rates, strict adherence to all methods of cultivation technology. The maximum yield of white annual clover seeds is formed under the condition of optimal ratio of all structural elements. In case of insufficient development of one structural element, the yield can be compensated at the expense of other components. Since individual elements of the structure are formed at different stages of organogenesis, different conditions are required for their successful development. In general, weather conditions during 2016-2018 were favorable for the growth and development of white annual clover plants and the formation of structural elements (table 1).

1. Structural indicators of white annual clover depending on varietal composition, row spacing and nitrogen fertilizer doses (average for 2016-2018)

\begin{tabular}{|c|c|c|c|c|c|c|}
\hline \multirow[t]{2}{*}{$\begin{array}{c}\text { Factor A } \\
- \\
\text { variety }\end{array}$} & \multirow[t]{2}{*}{$\begin{array}{c}\text { Factor B - } \\
\text { row spacing, } \\
\mathrm{cm}\end{array}$} & \multirow[t]{2}{*}{$\begin{array}{l}\text { Factor C - } \\
\text { dose of nitrogen } \\
\text { fertilizers, } \mathrm{kg} / \mathrm{ha}\end{array}$} & 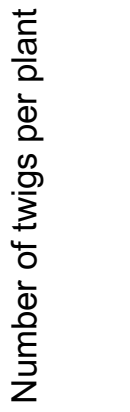 & 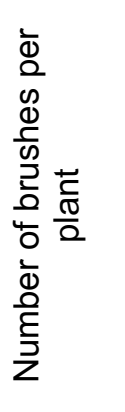 & 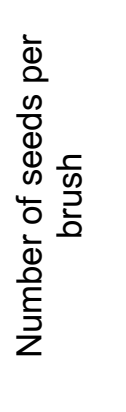 & \multirow[t]{2}{*}{$\begin{array}{l}0 \\
0 \\
0 \\
0 \\
\Phi \\
0 \\
0 \\
8 \\
8 \\
0 \\
\frac{1}{0} \\
0 \\
\frac{1}{0} \\
\frac{0}{0} \\
3\end{array}$} \\
\hline & & & \multicolumn{3}{|c|}{ pcs. } & \\
\hline \multirow{13}{*}{ 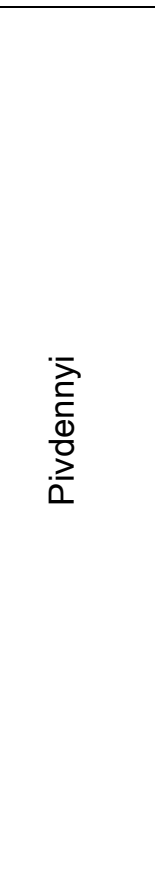 } & \multirow{4}{*}{15} & without fertilizers & 17,3 & 50,4 & 32,1 & 1,7 \\
\hline & & $\mathrm{N}_{30}$ & 18,1 & 57,6 & 34,1 & 1,7 \\
\hline & & $\mathrm{N}_{60}$ & 18,9 & 62,9 & 37,8 & 1,8 \\
\hline & & $\mathrm{N}_{90}$ & 17,8 & 61,2 & 36,2 & 1,7 \\
\hline & \multirow{4}{*}{30} & without fertilizers & 19,5 & 55,2 & 35,4 & 1,7 \\
\hline & & $\mathrm{N}_{30}$ & 21,5 & 62,4 & 38,4 & 1,9 \\
\hline & & $\mathrm{N}_{60}$ & 24,3 & 69,8 & 40,3 & $\overline{1,9}$ \\
\hline & & $\mathrm{N}_{90}$ & 22,6 & 67,4 & 39,5 & 1,9 \\
\hline & \multirow{4}{*}{45} & without fertilizers & 20,0 & 61,9 & 39,0 & 1,9 \\
\hline & & $\mathrm{N}_{30}$ & 24,0 & 71,3 & 46,2 & 2,0 \\
\hline & & $\mathrm{N}_{60}$ & 25,3 & 75,2 & 49,1 & 2,0 \\
\hline & & $\mathrm{N}_{90}$ & 24,5 & 72,5 & 47,1 & 2,0 \\
\hline & & without fertilizers & 20,2 & 61,4 & 43,7 & 1,9 \\
\hline
\end{tabular}




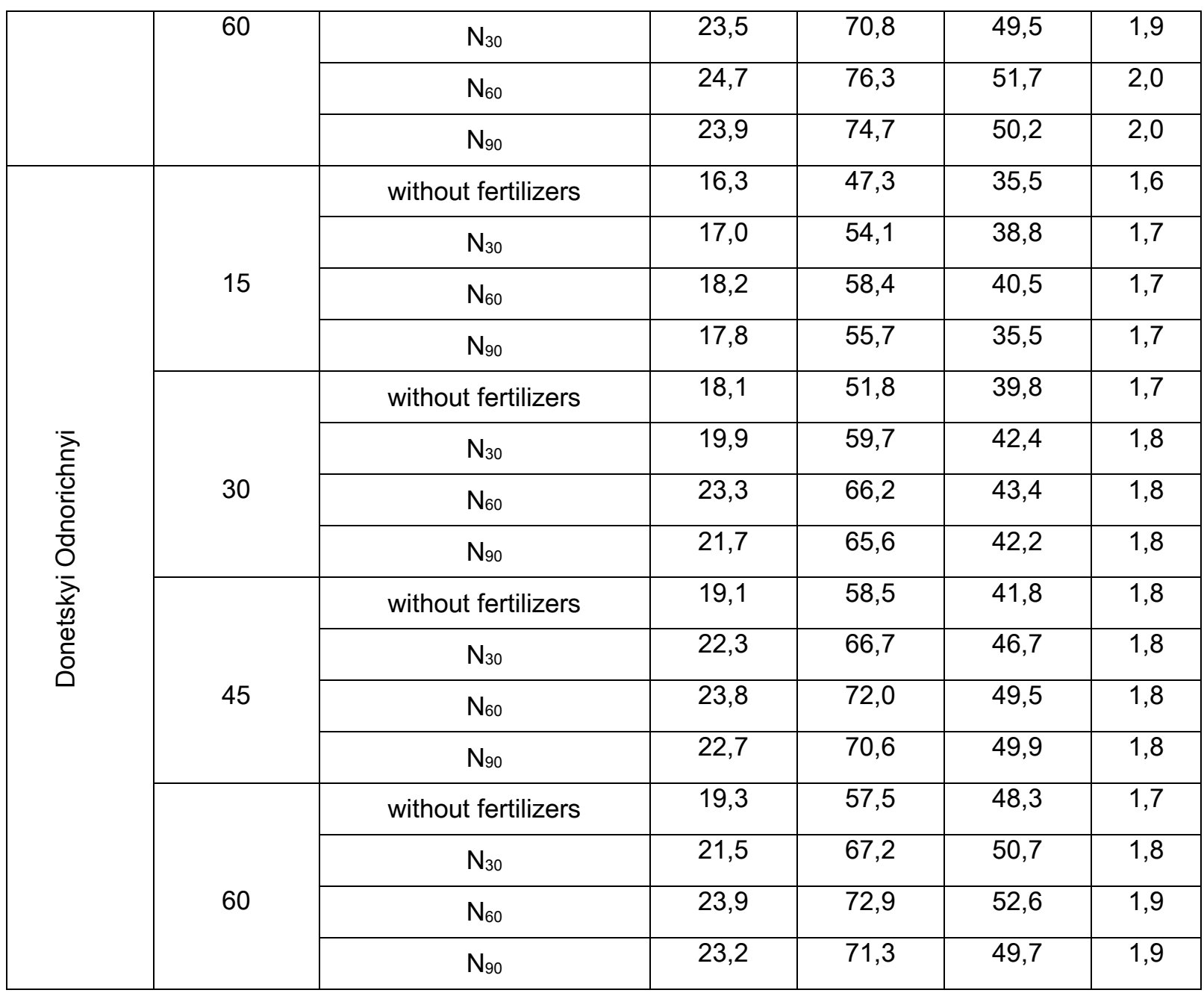

The analysis of the table shows that the structural indicators of white clover plants over the years of research depended on all factors of the experiment. The number of twigs on the plant in the cultivar Pivdennyi on an unfertilized background, depending on the width of the rows, was 17,3-22,1 pcs., In the cultivar Donetsk annual in control variants there is a decrease to $16,3-19,3$ pcs. $-12,7 \%$. With the use of nitrogen fertilizers in doses of 30,60 and $90 \mathrm{~kg}$ of active substance per 1 ha, this figure increased for all methods of sowing. The largest number of twigs per 1 plant was formed with a row spacing of 45 $\mathrm{cm}$, which on average in the experiment in the variants with the use of fertilizers was 23,8 pieces, which is $1,2-24,4 \%$ higher than in the variants with the application of fertilizers for another row spacing.

The number of tassels on the plant was the maximum in the variants with the use of nitrogen fertilizer at a dose of $60 \mathrm{~kg}$ of active substance per 1 ha and a row spacing of $45 \mathrm{~cm}$ in accordance. In varieties Donetsk annual and South, it was 72,9 and 76,3 pieces in accordance. In the variants with a decrease in the dose of nitrogen fertilizer to $\mathrm{N}_{30}$ or an increase to $\mathrm{N}_{90}$, this figure decreased by $4,8-5,1 \%$ for the same row spacing, and the lowest number of brushes was on the background of control without fertilizers and was 57,2 and 55,3 pcs. per 1 plant. Nitrogen fertilizers had a positive effect on the formation of the number of seeds per 1 brush and the weight of 1000 seeds. It should be noted that the maximum number of seeds on the 1st brush of clover plants of both varieties was formed using nitrogen fertilizer at a dose of $60 \mathrm{~kg}$ of active substance per 1 ha.

Studies have confirmed that, depending on the factors of the experiment, plants fall into different agrometeorological conditions, grow and develop differently, and therefore form different seed yields (table 2).

Thus, the seed productivity of white annual clover was influenced by all experimental factors. Seed yield of the studied varieties of white annual clover with different indicators of row spacing and nitrogen fertilizer application dose was $280-556 \mathrm{~kg} / \mathrm{ha}$. On average, over the years of research, the maximum seed yield $-556 \mathrm{~kg} / \mathrm{ha}$ was obtained by sowing clover white annual variety South with a row spacing of $45 \mathrm{~cm}$ and a dose of nitrogen fertilizer $\mathrm{N}_{60}\left(\mathrm{NSR}_{05} \mathrm{~A}-1,83 \mathrm{~kg} / \mathrm{ha}, \mathrm{B}-2,65, \mathrm{C}-2,16 \mathrm{~kg} / \mathrm{ha}\right.$ ).

2. The yield of seeds of annual white sweet clover of various varieties, depending on the width of the row spacing and doses of nitrogen fertilization (average for 2016-2018) 


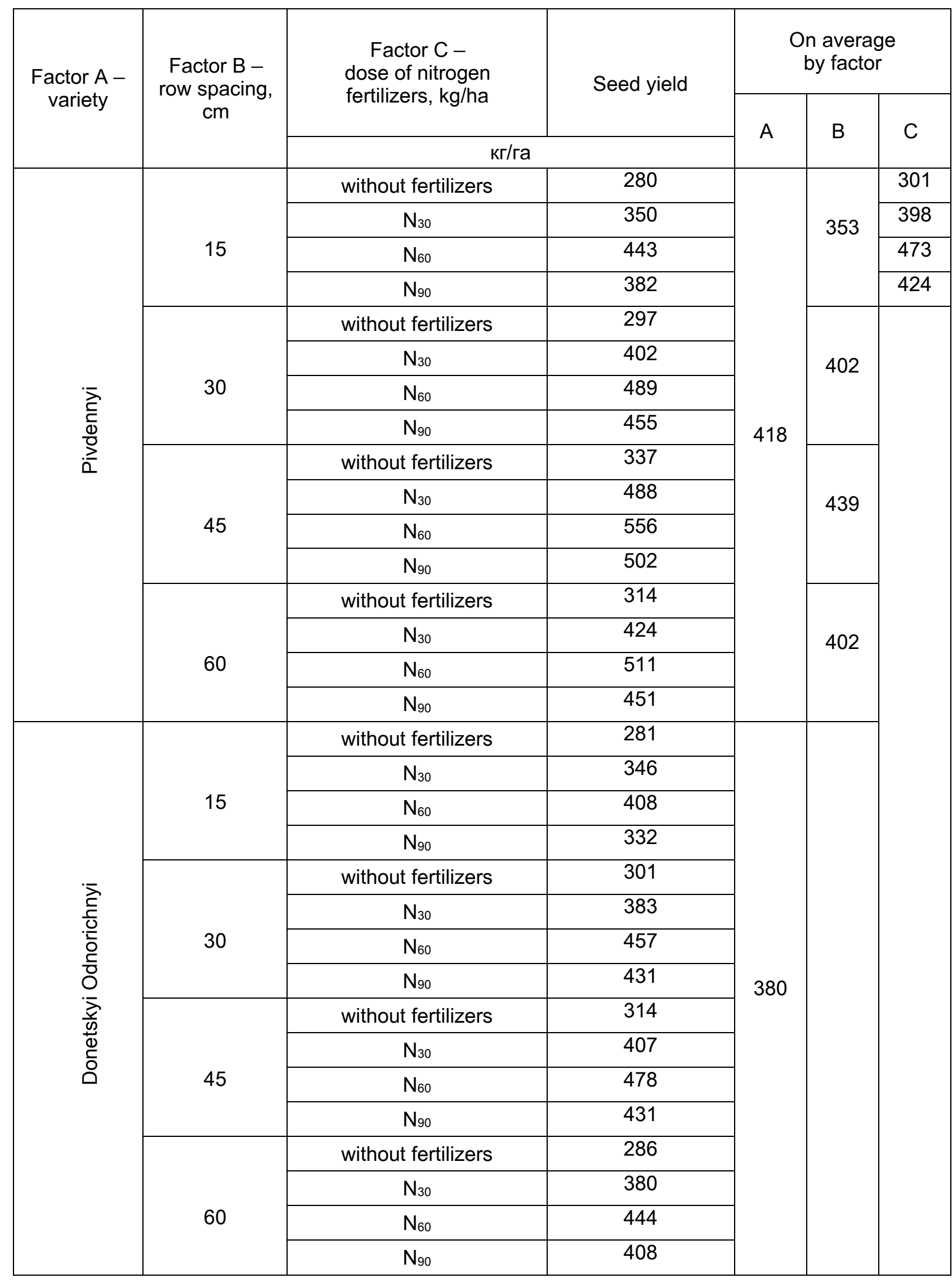

Assessment of materiality of partial differences

$\mathrm{NSR}_{05}, \mathrm{~kg} / \mathrm{ha:} \mathrm{A}=7,34 ; \mathrm{B}=7,50 ; \mathrm{C}=6,12$.

Assessment of the materiality of the average (main) effects

NSR $05, \mathrm{~kg} / \mathrm{ha}: \mathrm{A}=1,83 ; \mathrm{B}=2,65 ; \mathrm{C}=2,16$.

The maximum average yield of clover seeds $-418 \mathrm{~kg} / \mathrm{ha}$ (by factor $\mathrm{A}$ ) was obtained in the South variety. The change in row width also significantly affected the yield of crop seeds. For $45 \mathrm{~cm}$ row spacing (on average by factor B) the highest seed yield was obtained $-439 \mathrm{~kg} / \mathrm{ha}$. According to the 
factor $C$ (dose of nitrogen fertilizer), the maximum yield of white annual clover seeds was according to the norms of nitrogen fertilizers $\mathrm{N}_{60}$. Analysis of variance found that the formation of crop seed yield in 2016-2018 was most influenced by factor $C$ (nitrogen fertilizer application dose) $-71,1 \%$. The share of the influence of factor $A$ was $6,3 \%, B-17,2 \%$.

Studies in 2016-2018 found that the formation of seed yield of the studied crop significantly depended on the use of a dose of nitrogen fertilizer. Nitrogen fertilizers significantly increased the seed yield of both studied varieties. If in the control variant the yield indicators were $280-337 \mathrm{~kg} / \mathrm{ha}$, then in the variants with nitrogen application the doses $N_{30}, N_{60}$ and $N_{90}$ increased to $332-556 \mathrm{~kg} / \mathrm{ha}$, or by $15,7-$ $39,4 \%$

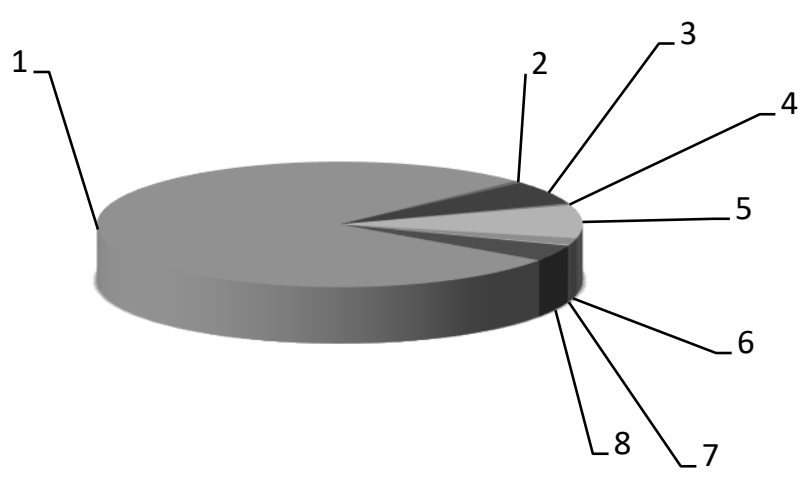

The share of the influence of experimental factors on the yield of white annual clover seeds (2016-2018),\%: 1 - factor C (71,1\%); 2 - factor $A$ (6,3\%); 3 - AB interactions (1,6\%); 4 interactions of the $A C(1,1 \%) ; 5$ - factor $B(17,2 \%) ; 6-A B C$ interactions $(0,4 \%) ; 7$-residues $(0,3 \%) ; 8$ - interactions of the $B C(2,1 \%)$

\section{Conclusions}

According to the results of the research, the optimal width between rows and the dose of nitrogen fertilizer were established, which are guaranteed to provide optimal structural indicators and high yield of seeds of cultivars in non-irrigated conditions of the South of Ukraine. Weather conditions during the research period in 2016-2018 were favorable for the growth and development of white annual clover plants and the formation of structural elements. It was found that the greatest influence on the formation of seed productivity of the crop had a dose of nitrogen fertilizer (factor C) $-71,1 \%$, the share of varietal composition (factor A) was 6,3\%, row spacing (factor B) - 17,2\%. On average, in 2016-2018, the maximum seed yield of $556 \mathrm{~kg} / \mathrm{ha}$ was obtained by sowing white white annual varieties of Pivdenny using a row spacing of $45 \mathrm{~cm}$ and applying a dose of $\mathrm{N}_{60}$ nitrogen fertilizer.

\section{References}

1. Kokhan, A.V., Kavalir, L.V., \& Samoilenko, O.A. (2018). Selektsiia ta nasinnytstvo odnorichnykh $i$ bahatorichnykh kormovykh trav: teoretychni ta praktychni aspekty [Breeding and seed production of annual and perennial fodder grasses: theoretical and practical aspects]. Poltava: Astraia. [In Ukrainian].

2. Zernovi bobovi. Rekomendatsii z vyroshchuvannia [Cereal legumes. Growing recommendations]. (2017). Kompaniia BASF Agro. [In Ukrainian].

3. Demydov, O. A., \& Demianiuk, O. S. (2017).Vplyv ahro- ekolohichnykh chynnykiv na vmist mikrobnoi biomasy u grunti [Influence of agri-environmental factors on the content of microbial biomass in soil]. Taurian Scientific Bulletin. Agricultural sciences, 97, 39 - 44. [In Ukrainian].

4. Lykhochvor, V. V., \& Petrychenko, V. F. (2012). Mineralni dobryva ta yikh zastosuvannia [Mineral fertilizers and their application. 2nd ed., Corrected, supplemented]. Lviv: Ukrainski tekhnolohii. [In Ukrainian].

5. Rudnichenko, N. (2019). Pryrodni liky dlia gruntu i dzherelo bilka dlia liudstva [Natural medicine for the soil and a source of protein for mankind]. Offer, 1, $24-29$. [In Ukrainian].

6. Petrychenko, V. F., \& Lykhochvor, V. V. (2019). Roslynnytstvo. Novi tekhnolohii vyroshchuvannia silskohospodarskykh kultur [Crop production. New technologies for growing crops. 5th ed., Corrected, supplemented]. Lviv: Ukrainski tekhnolohii. [In Ukrainian].

7. Kalenska, S.M., Zhuravlova, N.V., \& Maksymenko, O.I. (2005). Roslynnytstvo [Crop production: textbook]. Kyiv. [In Ukrainian].

8. Min, W., Hofen, O., \& Tompson, R. (2018). A global perspective on agroecosystem nitrogen cycles after returning crop residue. Agriculture, Ecosystems \& Environment, 266, 49 - 54. 
9. Özköse, A., \& Tamkoç, A. (2016). Determination of Agricultural Characteristics of Smooth Bromegrass (Bromus inermis Leyss) Lines under Konya Regional Conditions. International Journal of Biological, Biomolecular, Agricultural, Food and Biotechnological Engineering, 10, 11, $681-684$.

10. Kovalenko, N.P. (2014). Stanovlennia ta rozvytok naukovo-orhanizatsiinykh osnov zastosuvannia vitchyznianykh sivozmin u systemakh zemlerobstva (druha polovyna KhIKh pochatok $\mathrm{KhKhl}$ st.) [Becoming and development of scientifically-organizational bases of application of home crop rotations in the systems of agriculture (second half of XIX - beginning of XXI of century)]. Kyiv: TOV «Niland-LTD».

11. Lyakh, N.M. (2018). Vliyanie dlitelnogo primeneniya mineralnykh udobreniy na fizikokhimicheskie svoystva chernozema vyshchelochennogo [Influence of long-term application of mineral fertilizers on physicochemical properties of leached chernozem]. Agrochemistry and soil science, 1, $147-148$. [in Russian].

12. Kirilesku, O.L., \& Movchan, K.I. (2016). Formuvannia vrozhainosti zernobobovykh kultur v umovakh Zakhidnoho Lisostepu Ukrainy [Formation of legume yields in the Western ForestSteppe of Ukraine]. Feed and feed production, 82, 127 - 132. [In Ukrainian].

13. Vozhehova, R. A., Lavrynenko, Yu. O., \& Maliarchuk, M. P. (2014). Metodyka polovykh $i$ laboratornykh doslidzhen na zroshuvanykh zemliakh [Methods of field and laboratory research on irrigated lands]. Kherson: Hrin D.S. [In Ukrainian].

14. Ushkarenko, V.O., Nikishenko, V.L., Holoborodko, S.P., \& Kokovikhin, S.V. (2009). Dyspersiinyi $i$ koreliatsiinyi analiz rezultativ polovykh doslidiv [Analysis of variance and correlation of the results of field experiments]. Kherson: Ailant. [In Ukrainian]. 